\title{
Transfer of Pectobacterium chrysanthemi
} (Burkholder et al. 1953) Brenner et al. 1973 and Brenneria paradisiaca to the genus Dickeya gen. nov. as Dickeya chrysanthemi comb. nov. and Dickeya paradisiaca comb. nov. and delineation of four novel species, Dickeya dadantii sp. nov., Dickeya dianthicola sp. nov., Dickeya dieffenbachiae sp. nov. and Dickeya zeae sp. nov.

Correspondence Régine Samson samson@angers.inra.fr

\section{INTRODUCTION}

Pectobacterium chrysanthemi (Burkholder et al. 1953) Brenner et al. 1973 emend. Hauben et al. 1998 was reinstated in the genus Pectobacterium Waldee 1945 after a long period of time during which Erwinia chrysanthemi Burkholder et al. 1953, its homotypic synonym (same type 
strain), was being used according to successive descriptions in Bergey's Manual of Determinative Bacteriology (Burkholder, 1957) and Bergey's Manual of Systematic Bacteriology (Lelliott \& Dickey, 1984).

The species E. chrysanthemi was created for the Chrysanthemum morifolium hollow stalk agent (Burkholder et al., 1953). Similar bacteria were subsequently isolated from soft rots and wilts of numerous diseased plant species (CABI, 2001). After extensive biochemical studies (Martinec \& Kocur, 1963; Graham, 1964, 1972; Dye, 1969) and for the elaboration of the Approved Lists (Skerman et al., 1980), all isolates were finally gathered into a single species, E. chrysanthemi. For convenience, phytobacteriologists divided E. chrysanthemi into six pathovars, pv. chrysanthemi, pv. dianthicola, pv. dieffenbachiae, pv. parthenii, pv. zeae and pv. paradisiaca (Young et al., 1978; Lelliott \& Dickey, 1984). E. chrysanthemi pv. paradisiaca was renamed Brenneria paradisiaca (Hauben et al., 1998) on the basis of $16 \mathrm{~S}$ rRNA gene sequences, whereas E. chrysanthemi remained clustered with members of the genus Pectobacterium. In order to designate in this study all strains formerly included in $E$. chrysanthemi sensu stricto (Lelliott \& Dickey, 1984), i.e. belonging either to $P$. chrysanthemi or to B. paradisiaca, the expression 'E. chrysanthemi complex' will be used.

Phenotypic diversity of strains of the E. chrysanthemi complex was demonstrated using classical tests, auxanograms and API galleries (Hildebrand et al., 1978; Dickey, 1979; Dickey \& Victoria, 1980; Thomson et al., 1981; Verdonck et al., 1987). However, the practice of using pathogenicity tests to define the affiliation of a strain to a given pathovar proved difficult to implement (Dickey, 1981; Janse \& Ruissen, 1988). As an alternative, nine biovars were proposed to characterize all strains of the complex by unambiguous differential biochemical tests (Samson \& Nassan-Agha, 1978; Samson et al., 1987, 1990; Ngwira \& Samson, 1990). Complementary methods, such as serology and DNA typing, revealed either uniformity or diversity within the E. chrysanthemi complex. A major O-serogroup (1) recognized many isolates from many plant species (Samson, 1973; Yakrus \& Schaad, 1979; Dickey et al., 1984). Other distinct O-serogroups were described that each recognized a few strains (Samson, 1973; Samson \& Nassan-Agha, 1978; Dickey et al., 1984, 1987; Samson et al., 1987, 1990). Ribotyping and PCR-RFLP studies showed large genomic heterogeneity of isolates of the $E$. chrysanthemi complex and allocated the strains to different groups that could be related to the biovar classification (Boccara et al., 1991; Nassar et al., 1994, 1996). The overall diversity of isolates of the E. chrysanthemi complex was pointed out again by amplified fragment length polymorphism (AFLP) studies (Avrova et al., 2002), but none of these works allowed clarification of its taxonomy.

Initial DNA relatedness studies (Brenner et al., 1977), although undertaken on a small number of strains, revealed that $P$. chrysanthemi could be divided into four DNA relatedness groups: one with Dieffenbachia isolates, one with
Chrysanthemum morifolium and Parthenium sp. isolates, one with maize isolates and one with a sugarcane isolate. The purpose of the present study was to scrutinize the whole diversity of a large collection of strains belonging to the $E$. chrysanthemi complex by using phenotypic characteristics, DNA-DNA hybridization, serology and 16S rRNA gene sequence analysis. The outcomes of this study were (i) the assignment of strains previously characterized as $P$. chrysanthemi and B. paradisiaca to a novel genus, Dickeya, and (ii) the delineation of six species within the novel genus.

\section{METHODS}

Bacterial strains. A total of 75 representative strains of $P$. chrysanthemi and the type strains of $B$. paradisiaca (CFBP $4178^{\mathrm{T}}$ ) and Pectobacterium cypripedii $\left(\mathrm{CFBP} 3613^{\mathrm{T}}\right.$ ) were used in this study (Table 1). The strains were isolated from various host plants and locations all over the world. The identity of the strains as belonging to the E. chrysanthemi complex was confirmed by pectinolytic activity, production of indole, utilization of $(+)$-L-arabinose, malonate and $(+)$-D-malate and non-utilization of trehalose (Gardan et al., 2003).

DNA extraction and DNA-DNA hybridization. Extraction and purification of DNA were performed as described by Brenner et al. (1982). Native DNA of five strains of P. chrysanthemi (CFBP $2048^{\mathrm{T}}$, CFBP $2052^{\mathrm{T}}$, CFBP $1269^{\mathrm{T}}$, CFBP $2051^{\mathrm{T}}$, CFBP 2015) and of B. paradisiaca CFBP 3477 was labelled in vitro by nick translation with tritium-labelled nucleotides (Amersham Biosciences). The S1 nuclease/trichloroacetic method was used as described by Crosa et al. (1973) with the modifications of Grimont et al. (1980). The $\Delta T_{\mathrm{m}}$ (thermal stability of reassociated DNA) was determined by using the method of Crosa et al. (1973).

Phenotypic tests and numerical taxonomy. Twenty-two conventional tests and assimilation of carbon sources using Biotype 100 strips (bioMérieux) were determined as described by Sutra et al. (2001). A total of 121 tests were included in a numerical taxonomy analysis for 68 strains of $P$. chrysanthemi, B. paradisiaca and P. cypripedii. The Jaccard coefficient was used for calculating the distance matrix and UPGMA was used to perform cluster analysis (Sneath \& Sokal, 1973). From the numerical analysis performed with TAXONUM software, calculation of a diagnostic ability coefficient allowed the selection of discriminatory phenotypic tests (Descamp \& Véron, 1981).

Serology. Polyclonal antibodies were produced in rabbits as described previously (Samson et al., 1987). Care was taken to ensure that the immunizing bacteria, as well as the tested bacteria, were motile, in order to ascertain the serotypes of the flagella ( $\mathrm{H}$ antigens) (Guillorit-Rondeau et al., 1996). Twelve O-serogroups and five H-types were delineated on the basis of indirect immunofluorescent staining of the bacterial cells, by preparing antiserum 174 with CFBP $2048^{\mathrm{T}}$, antiserum 35 with CFBP 1236, antiserum 71 with CFBP 1451, antiserum 74 with CFBP 1502, antiserum 85 with CFBP 1496, antiserum 231 with CFBP $2052^{\mathrm{T}}$, antiserum 228 with CFBP 1278, antiserum 263 with CFBP 1531, antiserum 268 with CFBP 1277, antiserum 273 with CFBP 1528, antiserum 277 with CFBP 3805 and antiserum 306 with CFBP 3804. The first typing step of the bacteria was performed after mixing the antisera (used in a 200-fold dilution) which contained the same $\mathrm{H}$ antibodies in order to establish the H-type. Antisera of each mixture of O-antibodies that gave a positive reaction for the cell walls (lipopolysaccharide recognition) were then tested separately to obtain the 
Table 1. Strains of the E. chrysanthemi complex (Pectobacterium chrysanthemi and Brenneria paradisiaca) used in this study, listed according to their biovar type

Serotyping results were determined in this study.

\begin{tabular}{|c|c|c|c|c|c|c|}
\hline \multicolumn{2}{|r|}{ Strain } & \multirow[t]{2}{*}{ Biovar } & \multirow[t]{2}{*}{ Pathovar } & \multirow[t]{2}{*}{ Host plant } & \multirow{2}{*}{$\begin{array}{l}\text { Geographical origin, } \\
\text { year of isolation }\end{array}$} & \multirow{2}{*}{$\begin{array}{l}\text { Results of } \\
\text { serotyping }\end{array}$} \\
\hline CFBP no. & Other designation(s) & & & & & \\
\hline 722 & & 1 & & Lycopersicon esculentum & France, 1965 & $\mathrm{O}: 1, \mathrm{H}: \mathrm{a}$ \\
\hline 795 & & 1 & dianthicola & Dianthus sp. & France, 1965 & $\mathrm{O}: 1, \mathrm{H}: \mathrm{a}$ \\
\hline $1200^{\mathrm{T} a}$ & $\mathrm{NCPPB} 453^{\mathrm{T}}$ & 1 & dianthicola & Dianthus caryophyllus & UK, 1956 & $\mathrm{O}: 1, \mathrm{H}: \mathrm{a}$ \\
\hline 1888 & & 1 & & Solanum tuberosum & France, 1978 & $\mathrm{O}: 1, \mathrm{H}: \mathrm{a}$ \\
\hline 1982 & & 1 & & Dahlia sp. & France, 1972 & $\mathrm{O}: 1, \mathrm{H}: \mathrm{a}$ \\
\hline 3265 & & 1 & & Cichorium intybus & France, 1983 & $\mathrm{O}: 1, \mathrm{H}: \mathrm{a}$ \\
\hline 3702 & & 1 & & Cynara scolymus & France, 1984 & $\mathrm{O}: 1, \mathrm{H}: \mathrm{a}$ \\
\hline 1247 & & 2 & dieffenbachiae & Dieffenbachia picta & USA, 1957 & $\mathrm{O}: 1, \mathrm{H}: \mathrm{a}$ \\
\hline 1360 & & 2 & dieffenbachiae & Dieffenbachia sp. & France, 1972 & $\mathrm{O}: 1, \mathrm{H}: ?$ \\
\hline $2051^{\mathrm{T} b}$ & NCPPB $2976^{\mathrm{T}}$ & 2 & dieffenbachiae & Dieffenbachia sp. & USA, 1957 & $\mathrm{O}: 1, \mathrm{H}: \mathrm{a}$ \\
\hline 3694 & & 2 & & Lycopersicon esculentum & Cuba, 1987 & $\mathrm{O}: 1, \mathrm{H}: ?$ \\
\hline 3698 & & 2 & & Musa sp. & Cuba, 1987 & $\mathrm{O}: 1, \mathrm{H}: \mathrm{a}$ \\
\hline $1269^{\mathrm{T}}$ & NCPPB $898^{\mathrm{T}}$, Hayward B374 ${ }^{\mathrm{T}}$ & 3 & & Pelargonium capitatum & Comoros, 1960 & $\mathrm{O}: 1, \mathrm{H}: \mathrm{a}$ \\
\hline 1277 & NCPPB 1863 & 3 & zeae & Zea mays & USA, 1966 & $\mathrm{O}: 9, \mathrm{H}: \mathrm{e}$ \\
\hline 1278 & NCPPB 1121 & 3 & & Ananas comosus & Malaysia, 1961 & $\mathrm{O}: 7, \mathrm{H}: \mathrm{a}$ \\
\hline 1496 & & 3 & zeae & Zea mays & France, 1973 & $\mathrm{O}: 5, \mathrm{H}: \mathrm{e}$ \\
\hline 1502 & & 3 & zeae & Zea mays & France, 1973 & $\mathrm{O}: 4, \mathrm{H}: \mathrm{d}$ \\
\hline 1533 & & 3 & zeae & Zea mays & Italy, 1970 & $\mathrm{O}: ?, \mathrm{H}: ?$ \\
\hline 1537 & & 3 & & Saccharum officinarum & Australia & $\mathrm{O}: 7, \mathrm{H}: ?$ \\
\hline 1613 & & 3 & & Euphorbia pulcherrima & France, 1974 & $\mathrm{O}: 1, \mathrm{H}: \mathrm{a}$ \\
\hline 1871 & & 3 & & Musa sp. & Ivory Coast, 1976 & $\mathrm{O}: ?, \mathrm{H}: ?$ \\
\hline 1884 & & 3 & & Brachiaria ruziziensis & Guyana (Fr.), 1979 & $\mathrm{O}: 11, \mathrm{H}: \mathrm{a}$ \\
\hline 2018 & & 3 & & Saintpaulia ionantha & France, 1977 & $\mathrm{O}: 1, \mathrm{H}: \mathrm{a}$ \\
\hline $2052^{\mathrm{T} c}$ & NCPPB $2538^{\mathrm{T}}$ & 3 & zeae & Zea mays & USA, 1970 & $\mathrm{O}: 6, \mathrm{H}: \mathrm{a}$ \\
\hline 2268 & & 3 & & Solanum tuberosum & Australia, 1978 & $\mathrm{O}: 6, \mathrm{H}: \mathrm{a}$ \\
\hline 3695 & & 3 & zeae & Zea mays & Cuba, 1987 & $\mathrm{O}: 1, \mathrm{H}: ?$ \\
\hline 3697 & & 3 & & Ipomoea batatas & Cuba, 1987 & $\mathrm{O}: 1, \mathrm{H}: \mathrm{a}$ \\
\hline 3707 & & 3 & & water & Israel, 1986 & $\mathrm{O}: 1, \mathrm{H}: ?$ \\
\hline 3780 & & 3 & & Dianthus sp. & Italy & $\mathrm{O}: 1, \mathrm{H}: \mathrm{a}$ \\
\hline 3781 & & 3 & & Dianthus sp. & Italy & $\mathrm{O}: 1, \mathrm{H}: \mathrm{a}$ \\
\hline 3782 & & 3 & & Dianthus sp. & Italy & $\mathrm{O}: 1, \mathrm{H}: \mathrm{a}$ \\
\hline 3783 & & 3 & & Dianthus sp. & Italy & $\mathrm{O}: 1, \mathrm{H}: \mathrm{a}$ \\
\hline 3804 & & 3 & & Nicotiana tabacum & Cuba & $\mathrm{O}: 12, \mathrm{H}: \mathrm{d}$ \\
\hline 3805 & & 3 & zeae & Zea mays & Senegal, 1986 & $\mathrm{O}: 11, \mathrm{H}: \mathrm{a}$ \\
\hline 3855 & Lemattre 3937 & 3 & & Saintpaulia ionantha & France, 1977 & $\mathrm{O}: 1, \mathrm{H}: \mathrm{a}$ \\
\hline 4148 & ICMP 7077 & 3 & & Oryza sativa & Japan, 1978 & $\mathrm{O}:$ ?, $\mathrm{H}: ?$ \\
\hline 4149 & ICMP 7078 & 3 & & Oryza sativa & Japan, 1978 & $\mathrm{O}: ?, \mathrm{H}: ?$ \\
\hline 4150 & ICMP 7079 & 3 & & Oryza sativa & Japan, 1978 & $\mathrm{O}: ?, \mathrm{H}: \mathrm{a}$ \\
\hline 4151 & ICMP 1566 & 3 & & Philodendron scandens & USA, 1959 & $\mathrm{O}: 6, \mathrm{H}: \mathrm{d}$ \\
\hline 4152 & ICMP 9156 & 3 & & Philodendron sp. & Greece, 1985 & $\mathrm{O}: 6, \mathrm{H}: \mathrm{d}$ \\
\hline 4153 & NCPPB 454 & 3 & & Philodendron sp. & USA, 1985 & $\mathrm{O}: 1, \mathrm{H}: \mathrm{d}$ \\
\hline 4176 & NCPPB 2339 & 3 & & Chrysanthemum morifolium & USA, 1970 & $\mathrm{O}: 6, \mathrm{H}: \mathrm{a}$ \\
\hline 4177 & & 3 & & Musa paradisiaca & Jamaica, 1970 & $\mathrm{O}: 1, \mathrm{H}: \mathrm{a}$ \\
\hline 4180 & & 3 & & Musa paradisiaca & Panama, 1972 & $\mathrm{O}: 1, \mathrm{H}: \mathrm{d}$ \\
\hline 6466 & & 3 & & Ananas comosus & Martinique (Fr.), 1991 & $\mathrm{O}: 10, \mathrm{H}: ?$ \\
\hline 6467 & & 3 & & Musa sp. & Martinique (Fr.), 1994 & $\mathrm{O}: 1, \mathrm{H}: \mathrm{a}$ \\
\hline 1445 & & 4 & paradisiaca & Musa paradisiaca & Colombia, 1972 & $\mathrm{O}: 3, \mathrm{H}: ?$ \\
\hline 1446 & & 4 & paradisiaca & Musa paradisiaca & Colombia, 1972 & $\mathrm{O}: 3, \mathrm{H}: ?$ \\
\hline 1451 & & 4 & paradisiaca & Musa paradisiaca & Colombia, 1972 & $\mathrm{O}: 3, \mathrm{H}: ?$ \\
\hline $3477^{d}$ & ICMP 2349, LMG 2545 & 4 & paradisiaca & Musa paradisiaca & Colombia, 1968 & $\mathrm{O}: 3, \mathrm{H}: ?$ \\
\hline
\end{tabular}


Table 1. cont.

\begin{tabular}{|c|c|c|c|c|c|c|}
\hline \multicolumn{2}{|r|}{ Strain } & \multirow[t]{2}{*}{ Biovar } & \multirow[t]{2}{*}{ Pathovar } & \multirow[t]{2}{*}{ Host plant } & \multirow{2}{*}{$\begin{array}{l}\text { Geographical origin, } \\
\text { year of isolation }\end{array}$} & \multirow{2}{*}{$\begin{array}{l}\text { Results of } \\
\text { serotyping }\end{array}$} \\
\hline CFBP no. & Other designation(s) & & & & & \\
\hline 3696 & & 4 & & Musa sp. & Cuba, 1987 & $\mathrm{O}: 3, \mathrm{H}: ?$ \\
\hline 3699 & & 4 & zeae & Zea mays & Cuba, 1987 & $\mathrm{O}: 3, \mathrm{H}: ?$ \\
\hline $4178^{\mathrm{T}}$ & NCPPB $2511^{\mathrm{T}}$ & 4 & paradisiaca & Musa paradisiaca & Colombia, 1970 & $\mathrm{O}: 3, \mathrm{H}: ?$ \\
\hline 1346 & & 5 & chrysanthemi & Chrysanthemum maximum & Italy, 1969 & $\mathrm{O}: 2, \mathrm{H}: ?$ \\
\hline $2048^{\mathrm{T}}$ & $\mathrm{NCPPB} 402^{\mathrm{T}}$ & 5 & chrysanthemi & Chrysanthemum morifolium & USA, 1958 & $\mathrm{O}: 1, \mathrm{H}: \mathrm{b}$ \\
\hline 3262 & & 5 & & Cichorium intybus & France, 1981 & $\mathrm{O}: 1, \mathrm{H}: \mathrm{b}$ \\
\hline 3700 & & 5 & & water & France, 1974 & $\mathrm{O}: 1, \mathrm{H}: ?$ \\
\hline 3701 & & 5 & & Lycopersicon esculentum & France, 1981 & $\mathrm{O}: 1, \mathrm{H}: ?$ \\
\hline 3703 & & 5 & & Helianthus annuus & France, 1986 & $\mathrm{O}: 1, \mathrm{H}: \mathrm{b}$ \\
\hline 1236 & NCPPB 1861 & 6 & parthenii & Parthenium argentatum & USA, 1945 & $\mathrm{O}: 2, \mathrm{H}: \mathrm{c}$ \\
\hline 1245 & & 6 & & Philodendron oxycardium & USA, 1959 & $\mathrm{O}: ?, \mathrm{H}: \mathrm{d}$ \\
\hline $1270^{e}$ & NCPPB 516 & 6 & parthenii & Parthenium argentatum & Denmark, 1957 & $\mathrm{O}: 2, \mathrm{H}: \mathrm{c}$ \\
\hline 3704 & & 6 & & Cynara scolymus & Réunion (Fr.), 1986 & $\mathrm{O}: 1, \mathrm{H}: \mathrm{a}$ \\
\hline 1276 & NCPPB 1385 & 7 & & Dahlia sp. & Romania, 1962 & $\mathrm{O}: 1, \mathrm{H}: ?$ \\
\hline $2015^{f}$ & & 7 & & Solanum tuberosum & France, 1975 & $\mathrm{O}: 1, \mathrm{H}: \mathrm{a}$ \\
\hline 3705 & & 7 & & Solanum tuberosum & Switzerland, 1986 & $\mathrm{O}: 1, \mathrm{H}: \mathrm{a}$ \\
\hline 3706 & & 7 & & Cichorium intybus & Switzerland, 1986 & $\mathrm{O}: 1, \mathrm{H}: \mathrm{a}$ \\
\hline $1447^{g}$ & NCPPB 2546 & 8 & zeae & Zea mays & India, 1969 & $\mathrm{O}: ?, \mathrm{H}: ?$ \\
\hline 1528 & NCPPB 2541 & 8 & zeae & Zea mays & USA, 1966 & $\mathrm{O}: 10, \mathrm{H}: \mathrm{a}$ \\
\hline 1531 & & 8 & zeae & Zea mays & USA, 1966 & $\mathrm{O}: 8, \mathrm{H}: \mathrm{a}$ \\
\hline 3708 & & 8 & zeae & Zea mays & USA, 1986 & $\mathrm{O}: ?, \mathrm{H}: \mathrm{a}$ \\
\hline $1805^{h}$ & & 9 & & Kalanchoe blossfeldiana & Denmark, 1977 & $\mathrm{O}: 1, \mathrm{H}: ?$ \\
\hline 2598 & & 9 & & Kalanchoe blossfeldiana & Switzerland, 1982 & $\mathrm{O}: 1, \mathrm{H}: \mathrm{a}$ \\
\hline 2982 & & 9 & & Kalanchoe blossfeldiana & France, 1987 & $\mathrm{O}: 1, \mathrm{H}: \mathrm{a}$ \\
\hline 4155 & & 9 & & Kalanchoe blossfeldiana & The Netherlands, 1985 & $\mathrm{O}: 1, \mathrm{H}: \mathrm{a}$ \\
\hline 4156 & & 9 & & Kalanchoe blossfeldiana & The Netherlands, 1985 & $\mathrm{O}: 1, \mathrm{H}: \mathrm{a}$ \\
\hline
\end{tabular}

${ }^{\star}$ Reference strains are indicated as follows: $a$, pv. dianthicola and biovar $1 ; b$, pv. dieffenbachiae and biovar 2; $c$, pv. zeae and biovar 3 ; $d$, pv. paradisiaca (B. paradisiaca) and biovar 4; e, pv. parthenii and biovar 6; $f$, biovar 7; $g$, biovar 8; $h$, biovar 9.

precise O-serogroup. The reactions were of a plus/minus type without cross-reactions between the O-serogroups, as explained by Janse \& Ruissen (1988).

Phylogenetic analyses. The $16 \mathrm{~S}$ rRNA gene sequences of $P$. chrysanthemi strains CFBP $1200^{\mathrm{T}}$, CFBP $1269^{\mathrm{T}}$, CFBP 1270 , CFBP $2051^{\mathrm{T}}$ and CFBP $2052^{\mathrm{T}}$ and B. paradisiaca CFBP $4178^{\mathrm{T}}$ were determined and the sequences were aligned by comparison within our database of 66000 already aligned bacterial 16S rRNA gene sequences. Selection of related sequences was according to previous phylogenetic analyses of the entire database and BLAST searches with CFBP $1269^{\mathrm{T}}$, CFBP $4178^{\mathrm{T}}$, CFBP $2052^{\mathrm{T}}$ and Brenneria rubrifaciens LMG $2709^{\mathrm{T}}$ against the latest release of EBI (http://www.ebi.ac.uk/). Alignments were refined manually within this subset of related sequences. Successive phylogenetic trees (from 250 to 19 sequences) were then constructed to determine to which subset of the global tree the new sequences could be related. When several sequences were available for a type strain, all sequences were included in the preliminary analysis (they often differed by a few nucleotides) and, if they formed a clade, a single one was chosen for the tree presented; this procedure led to the retention of a single sequence for each type strain. The exception was $P$. cypripedii, for which the three available sequences showed discrepancies of phylogeny. Detailed analyses showed that the sequence of $P$. cypripedii LMG $2657^{\mathrm{T}}$ (GenBank accession no. Z96094) (which appeared to be related to the new sequences) was not the sequence for the authentic strain (likely contamination), as it did not cluster with the two other sequences of type strains available; it was therefore excluded from the final analysis. The final analysis was restricted to a subset of 33 sequences, analysed using three different methods (BIONJ, maximum-likelihood and maximum-parsimony). For the neighbour-joining (BIONJ) analysis, distance matrices were calculated using Kimura's two-parameter correction. BIONJ was performed according to Gascuel (1997); maximum-likelihood and maximumparsimony were from PHYLIP (Felsenstein, 1995). Because of close relationships, no evident homoplasy was detected and almost the entire sequence corresponding to positions 29-1428 of the Brenneria alni sequence was used for this analysis. Phylogenetic trees were drawn using NJPLOT (Perrière \& Gouy, 1996). Finally, phylogenies were also investigated with sequences of gyrase and recA genes, but too few sequences were available.

\section{RESULTS AND DISCUSSION}

\section{DNA-DNA hybridization}

Six DNA hybridization groups were delineated and two strains belonging to biovar 3 remained unclustered (Table 2). DNA hybridization group 1 included 20 strains 
Table 2. Levels of DNA relatedness among E. chrysanthemi complex strains

Strain: 1, Dickeya zeae CFBP 2052 $2^{\mathrm{T}}$; 2, Dickeya dadantii CFBP 1269 ; 3, Dickeya dianthicola CFBP 2015; 4, Dickeya dieffenbachiae CFBP $2051^{\mathrm{T}}$; 5, Dickeya paradisiaca CFBP 3477; 6, Dickeya chrysanthemi CFBP $2048^{\mathrm{T}}$. Values shown are percentages of relative binding with labelled DNA from the relevant strain; $\Delta T_{\mathrm{m}}$ values are shown in ${ }^{\circ} \mathrm{C}$ in parentheses. NT, Not tested.

\begin{tabular}{|c|c|c|c|c|c|c|c|}
\hline Source of unlabelled DNA & Biovar & 1 & 2 & 3 & 4 & 5 & 6 \\
\hline CFBP $2052^{\mathrm{T}}$ & 3 & 100 & 38 & 31 & 40 & 21 & 47 \\
\hline CFBP 6466 & 3 & 99 & NT & NT & NT & NT & NT \\
\hline CFBP 1533 & 3 & 93 & NT & NT & NT & NT & NT \\
\hline CFBP 1884 & 3 & 84 & NT & NT & NT & NT & NT \\
\hline CFBP 2268 & 3 & 84 & NT & NT & NT & NT & NT \\
\hline CFBP 1871 & 3 & 80 & 34 & NT & NT & NT & NT \\
\hline CFBP 3804 & 3 & 80 & 39 & NT & NT & NT & NT \\
\hline CFBP 4148 & 3 & 80 & 29 & NT & NT & NT & NT \\
\hline CFBP 4149 & 3 & 72 & 28 & NT & NT & NT & NT \\
\hline CFBP 3708 & 8 & 83 & 30 & NT & NT & NT & NT \\
\hline CFBP 1531 & 8 & 81 & 38 & NT & NT & NT & NT \\
\hline CFBP 1447 & 8 & 80 & NT & 37 & NT & NT & NT \\
\hline CFBP 1528 & 8 & 76 & NT & NT & NT & NT & NT \\
\hline Mean \pm SD... & & $83 \cdot 6 \pm 8 \cdot 5$ & $34 \cdot 1 \pm 4 \cdot 5$ & $34 \pm 4 \cdot 2$ & & & \\
\hline \multicolumn{8}{|l|}{ Genomospecies 2 (D. dadantii) } \\
\hline CFBP $1269^{\mathrm{T}}$ & 3 & 41 & 100 & NT & NT & NT & NT \\
\hline CFBP 6467 & 3 & 38 & 96 & NT & NT & NT & NT \\
\hline CFBP 3697 & 3 & 40 & 92 & NT & NT & NT & NT \\
\hline CFBP 3780 & 3 & 43 & 90 & NT & NT & NT & NT \\
\hline CFBP 3855 & 3 & 42 & 82 & NT & NT & NT & NT \\
\hline CFBP 4151 & 3 & 41 & 73 & NT & NT & NT & NT \\
\hline CFBP 4152 & 3 & 42 & 73 & NT & NT & NT & NT \\
\hline CFBP 4153 & 3 & 40 & 71 & NT & NT & NT & NT \\
\hline CFBP 4180 & 3 & 50 & 69 & NT & NT & NT & NT \\
\hline Mean \pm SD... & & $41 \cdot 9 \pm 2 \cdot 8$ & $84 \cdot 8 \pm 9 \cdot 1$ & & & & \\
\hline \multicolumn{8}{|l|}{ Unclustered strains } \\
\hline CFBP 1278 & 3 & 54 & 28 & NT & NT & NT & NT \\
\hline CFBP 1537 & 3 & 41 & 39 & NT & NT & NT & NT \\
\hline Mean \pm SD... & & $47 \cdot 5 \pm 9 \cdot 2$ & $33 \cdot 5 \pm 7 \cdot 8$ & & & & \\
\hline \multicolumn{8}{|l|}{ Genomospecies 3 (D. chrysanthemi) } \\
\hline CFBP 1236 & 6 & NT & 44 & NT & 44 & 20 & 86 \\
\hline CFBP 1270 & 6 & 45 & NT & 42 & NT & 18 & 71 \\
\hline CFBP $2048^{\mathrm{T}}$ & 5 & 47 & NT & 43 & 39 & 17 & 100 \\
\hline CFBP 1346 & 5 & NT & NT & NT & NT & NT & 93 \\
\hline CFBP 3703 & 5 & NT & NT & NT & NT & NT & 92 \\
\hline
\end{tabular}


Table 2. cont.

\begin{tabular}{|c|c|c|c|c|c|c|c|}
\hline Source of unlabelled DNA & Biovar & 1 & 2 & 3 & 4 & 5 & 6 \\
\hline CFBP 3262 & 5 & NT & NT & NT & NT & NT & 84 \\
\hline CFBP 3701 & 5 & NT & NT & NT & NT & NT & 83 \\
\hline Mean \pm SD... & & $46 \pm 1 \cdot 4$ & & $42 \cdot 5 \pm 0 \cdot 7$ & $41 \cdot 5 \pm 3 \cdot 5$ & $18 \cdot 3 \pm 1 \cdot 5$ & $87 \pm 9 \cdot 2$ \\
\hline \multicolumn{8}{|l|}{ Genomospecies 4 (D. dieffenbachiae) } \\
\hline CFBP $2051^{\mathrm{T}}$ & 2 & 40 & NT & 53 & 100 & 25 & 38 \\
\hline CFBP 1360 & 2 & NT & NT & NT & 96 & NT & NT \\
\hline CFBP 1247 & 2 & NT & NT & NT & 93 & NT & NT \\
\hline CFBP 3694 & 2 & NT & NT & NT & $75(2 \cdot 9)$ & NT & NT \\
\hline CFBP 3698 & 2 & NT & NT & NT & $73(1 \cdot 7)$ & NT & NT \\
\hline Mean \pm SD... & & & & & $84 \cdot 3 \pm 11 \cdot 9$ & & \\
\hline \multicolumn{8}{|l|}{ Genomospecies 5 (D. dianthicola) } \\
\hline CFBP 2015 & 7 & 44 & NT & 100 & 53 & 26 & 43 \\
\hline CFBP 1276 & 7 & NT & NT & 82 & NT & NT & NT \\
\hline CFBP 3705 & 7 & NT & NT & 80 & NT & NT & NT \\
\hline CFBP 3706 & 7 & NT & NT & 80 & NT & NT & NT \\
\hline CFBP 1888 & 1 & NT & NT & 97 & NT & NT & NT \\
\hline CFBP 722 & 1 & NT & NT & 95 & NT & NT & NT \\
\hline CFBP 3702 & 1 & NT & NT & 92 & NT & NT & NT \\
\hline CFBP $1200^{\mathrm{T}}$ & 1 & 38 & NT & 90 & NT & NT & NT \\
\hline CFBP 1982 & 1 & NT & NT & 81 & NT & NT & NT \\
\hline CFBP 3265 & 1 & NT & NT & 71 & NT & NT & NT \\
\hline CFBP 4156 & 9 & 37 & NT & 82 & NT & NT & NT \\
\hline CFBP 1805 & 9 & 39 & NT & 79 & NT & NT & NT \\
\hline CFBP 2598 & 9 & NT & NT & 78 & NT & NT & NT \\
\hline CFBP 4155 & 9 & 36 & NT & 77 & NT & NT & NT \\
\hline CFBP 2982 & 9 & NT & NT & 75 & NT & NT & NT \\
\hline Mean \pm SD... & & $38 \cdot 8 \pm 3 \cdot 1$ & & $72 \cdot 7 \pm 21 \cdot 4$ & & & \\
\hline \multicolumn{8}{|l|}{ Genomospecies 6 (D. paradisiaca) } \\
\hline CFBP 3477 & 4 & 21 & NT & 23 & 18 & 100 & 19 \\
\hline CFBP $4178^{\mathrm{T}}$ & 4 & NT & NT & NT & NT & 100 & NT \\
\hline CFBP 1446 & 4 & NT & NT & NT & NT & 100 & NT \\
\hline CFBP 1451 & 4 & NT & NT & NT & NT & 100 & NT \\
\hline CFBP 3699 & 4 & NT & NT & NT & NT & 100 & NT \\
\hline CFBP 1445 & 4 & NT & NT & NT & NT & 98 & NT \\
\hline CFBP 3696 & 4 & NT & NT & NT & NT & 93 & NT \\
\hline Mean \pm SD... & & & & & & $98 \cdot 9 \pm 2 \cdot 5$ & \\
\hline
\end{tabular}

belonging to biovars 3 and 8 that demonstrated 72-100\% relatedness to strain CFBP $2052^{\mathrm{T}}$. Strains of the other groups were $21-54 \%$ related to strain CFBP $2052^{\mathrm{T}}$. Thus, these 20 strains constituted genomic species 1 . DNA hybridization group 2 included 16 strains out of 34 belonging to biovar 3 that demonstrated 69-100\% relatedness to strain CFBP $1269^{\mathrm{T}}$. Strains of the other groups were $28-44 \%$ related to strain CFBP $1269^{\mathrm{T}}$. Thus, these 16 strains constituted genomospecies 2. Two strains of biovar 3 (CFBP 1278 and CFBP 1537) remained unclustered, since they were only loosely related to strain CFBP $2052^{\mathrm{T}}$ or strain CFBP $1269^{\mathrm{T}}$. DNA hybridization group 3 included seven strains (biovars 5 and 6) that demonstrated $71-100 \%$ relatedness to the type strain of $P$. chrysanthemi (CFBP $2048^{\mathrm{T}}$ ). Strains of the other groups were $19-47 \%$ related to strain CFBP $2048^{\mathrm{T}}$. Thus, these seven strains constituted genomospecies 3. DNA hybridization group 4 included five strains of biovar 2 that demonstrated 73-100\% relatedness to strain CFBP $2051^{\mathrm{T}}$, with $\Delta T_{\mathrm{m}}$ values of 1.7 and $2.9^{\circ} \mathrm{C}$ for the lowest values, 73 and $75 \%$, respectively. Strains of the other groups were $18-53 \%$ related to strain CFBP $2051^{\mathrm{T}}$. Thus, these strains constituted genomospecies 4 . DNA hybridization group 5 included 15 strains belonging to biovar 1 (six strains), biovar 7 (four strains) and biovar 9 (five strains) that demonstrated 71-100\% relatedness to strain CFBP 2015. Strains of the other groups were 23-53\% related to strain CFBP 2015. Thus, these 15 strains constituted genomospecies 5. DNA hybridization group 6 included six strains that were 93-100\% related to the strain CFBP 3477. Strains of the other groups were 17-26\% related to strain CFBP 3477. Thus, these six strains constituted genomospecies 6 , which corresponded to B. paradisiaca as delineated by Hauben et al. 
(1998). DNA hybridization tests performed between $P$. cypripedii CFBP $3613^{\mathrm{T}}$ and B. paradisiaca CFBP 3477 gave a mean of only $6.3 \%$ relatedness (data not shown in Table 2 ), showing that $P$. cypripedii was very distantly related to the six genomic species described here.

Three of the six genomic species delineated in the present study were shown to correspond to three DNA hybridization groups reported by Brenner et al. (1977), because of common strains present in the two studies. Genomic species 3 , corresponding to Brenner's group 1, contained the type strain CFBP $2048^{\mathrm{T}}$ along with other Chrysanthemum sp. and Parthenium sp. isolates. Genomospecies 4, corresponding to Brenner's group 2, contained two strains in common (CFBP $2051^{\mathrm{T}}$ and CFBP 1247). Genomospecies 1, corresponding to Brenner's group 3, contained several strains in common (CFBP 1277, CFBP 1528 and CFBP 1533). Two other results obtained by Brenner et al. (1977) showed the consistency of the two DNA hybridization classifications. CFBP 1276 (a Dahlia isolate) belonged to our genomospecies 5 and was excluded from Brenner's hybridization groups. The fourth hybridization group of Brenner et al. (1977) was defined by CFBP 1537. We found that CFBP 1537 was excluded from all six of our genomic species. CFBP 1537 could therefore constitute a candidate for a seventh genomic species of the E. chrysanthemi complex. Thus, the study of Brenner et al. (1977) and the present one fit perfectly. In addition to Brenner's groups, we delineated two new hybridization groups, genomospecies 6 for B. paradisiaca, which, although a described species, has not yet been confirmed as a species according to the criteria of Wayne et al. (1987), and genomospecies 2, whose type strain CFBP $1269^{\mathrm{T}}$ (=Hayward $\mathrm{B} 374^{\mathrm{T}}$ ), isolated from Pelargonium capitatum (Rasolofo \& Dadant, 1962), is often used for fundamental studies. It is remarkable that only two genomic species (genomospecies 1 and genomospecies 2) harboured 20 and 16 strains, respectively, out of 38 strains that were isolated from 16 different plant species in 17 countries.

\section{Phenotypic characteristics}

The dendrogram of phenotypic distances among 70 strains (68 strains of $P$. chrysanthemi and the type strains of $B$. paradisiaca and P. cypripedii) is shown in Fig. 1. At a distance of $0 \cdot 2$, six phena and one unclustered strain $(P$. cypripedii) were observed. The phenotypic characteristics that differentiate the six phena and $P$. cypripedii were deduced from the numerical taxonomic analysis (Table 3 ). The phena matched the genotypic groups, with the exception of phenon 1.

Phenon 1 included 33 strains that all belonged to former biovars 3 or 8 . At a distance of $0 \cdot 115$, the first 18 strains constituted a subphenon (not shown on the dendrogram) which grouped together $79 \%$ of the strains of genomospecies 1. Actually, phenon 1 clustered four genomic entities: Dickeya zeae sp. nov., Dickeya dadantii sp. nov. and two genomically distinct strains, CFBP 1278 and CFBP 1537. Four carbon sources [ $\alpha$-lactose, 1-o-methyl $\beta$-galactopyranoside, $\beta$-gentiobiose and $(+)$-L-tartrate] yielded two exclusive patterns, ++-+ versus --+- , for almost half of the strains of the two species (Table 4). Nevertheless, variations in one or two reactions of the other half of the strains required the use of two more carbon sources to allocate all strains to the four entities of phenon 1.

Phenon 2 (including all four studied strains of former biovar 6) and phenon 4 (including all five studied strains of former biovar 5 including the type strain of $P$. chrysanthemi, CFBP $2048^{\mathrm{T}}$ ) belonged to the same genomic species (Dickeya chrysanthemi sp. nov.), which could be distinguished from the other phena on the basis of (-)-Darabinose assimilation and growth at $39^{\circ} \mathrm{C}$ (Table 3). The existence of two clearly distinct phena in the latter species led to the creation of two biovars named after the pathovars they came from: bv. parthenii for phenon 2 and bv. chrysanthemi for phenon 4 . These two biovars differed from each other by inulin utilization and Moeller's arginine alkalinization (Table 3).

Phenon 3 included all five studied strains of former biovar 2 and corresponded to the genomic species Dickeya dieffenbachiae sp. nov. Phenon 5 included all 16 studied strains of former biovars 1, 7 and 9 and corresponded to the genomic species Dickeya dianthicola sp. nov. Phenon 6 included all six studied strains of former biovar 4 with $B$. paradisiaca CFBP $4178^{\mathrm{T}}$ and corresponded to the genomic species Dickeya paradisiaca sp. nov. Table 3 shows characteristics useful for differentiating the six above-mentioned genomic species.

As expected, the phenotypic study yielded the summing-up of all differential criteria reported previously and in this study for the E. chrysanthemi complex (Dickey, 1979; Dickey \& Victoria, 1980; Thomson et al., 1981; Verdonck et al., 1987; Samson et al., 1987). The novelty of this study consisted of the help of the TAXONUM software to select the traits that contributed most to the cut realized on the dendrogram at a distance $(0 \cdot 2)$ chosen on the basis of the DNA relatedness of the strains. A surprising result was provided by strains of former biovars 3 and 8 , which presented phenotypic features rather similar to each other although they belonged to two main genomic species: Dickeya zeae and Dickeya dadantii. Table 4 provides identification criteria for the two species but we admit that, in order to identify large numbers of isolates of phenon 1 and to get more clear-cut characteristics, alternative phenotypic criteria must be looked for. Notice that all Zea mays isolates of phenon 1 (originating from five countries) belonged to Dickeya zeae, but seven other sources are reported for this bacterial species (Table 1).

\section{Serological typing}

The majority of the studied strains (43 out of 76) belonged to O-serogroup 1 (Table 1), which was present in all biovars and genomic species, with the exception of biovar 4 (genomospecies 6 including $B$. paradisiaca), whose seven 


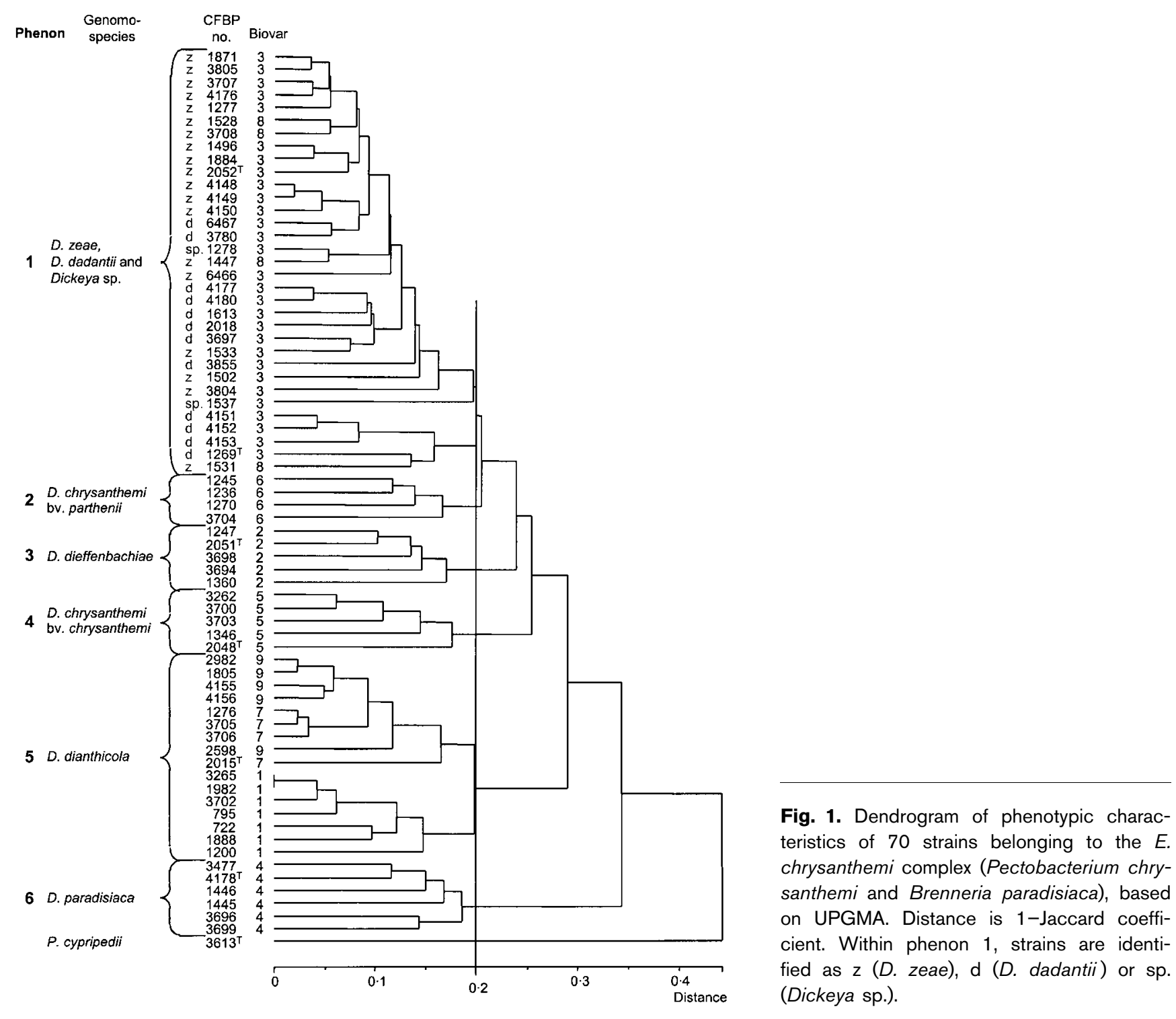

strains belonged specifically to $\mathrm{O}$-serogroup 3 . The other $\mathrm{O}$ serogroups were represented by one to four strains, and six strains did not belong to any of the 12 described Oserogroups. $\mathrm{H}$ : a-type flagella were predominant, as they were borne by 39 strains. Five strains were not H-typed because they were non-motile and 17 strains displayed flagella that were not recognized in any of the five $\mathrm{H}$ serotypes. Genomospecies 4 and genomospecies 5 contained 14 of 16 strains with the serological formula $\mathrm{O}: 1, \mathrm{H}: \mathrm{a}$. Genomospecies 3 displayed the serogroups $\mathrm{O}: 1$ and $\mathrm{O}: 2$ independently of the two phena (bv. chrysanthemi or bv. parthenii). Within genomospecies 2, 14 strains fell in serogroup $\mathrm{O}: 1$ against two strains only in serogroup $O: 6$. The greatest diversity was observed in genomospecies 1 , whose strains were either distributed into nine $\mathrm{O}$ serogroups or non-typed (Table 4). Surprisingly, the two strains (CFBP 1278 and CFBP 1537) of phenon 1 that did not hybridize with any of the genomic species both reacted in a particular serogroup, $0: 7$.

\section{Phylogenetic analyses}

Results of the phylogenetic analyses of 16S rRNA gene sequences (Fig. 2) showed that (i) all strains of P. chrysanthemi and $B$. paradisiaca were grouped within a robust clade, identified by all methods and $89 \%$ of bootstrap replications, thus suggesting that they could be grouped within a single taxon, which we propose to name genus Dickeya, and (ii) Pectobacterium carotovorum formed a robust clade that was distant from the aforementioned clade, and the depths of the internal branches suggest that several species could be recognized, as published by Gardan et al. (2003). The sequences for P. cypripedii DSM $3873^{\mathrm{T}}$ (GenBank accession numbers Z96094 and AJ233413) and the type strains of Brenneria salicis, Brenneria nigrifluens and B. rubrifaciens were included in the tree.

The transfer of $B$. paradisiaca to a novel genus should not raise questions, as all Brenneria species, including B. salicis, 
Table 3. Characteristics that differentiate phena 1 to 6 (Dickeya species) and Pectobacterium cypripedii as delineated in Fig. 1

,$+ 90-100 \%$ of strains positive;,$- 90-100 \%$ of strains negative; $\mathrm{d}(n)$, percentage of positive strains.

\begin{tabular}{|c|c|c|c|c|c|c|c|}
\hline Characteristic & Phenon 1 & Phenon 2 & Phenon 4 & Phenon 3 & Phenon 5 & Phenon 6 & P. cypripedii \\
\hline$(-)$-D-Tartrate & - & $\mathrm{d}(25)$ & - & - & + & + & + \\
\hline Lactose & + & $\mathrm{d}(75)$ & $\mathrm{d}(20)$ & - & - & $\mathrm{d}(17)$ & + \\
\hline Growth at $39^{\circ} \mathrm{C}$ & + & + & + & + & - & $\mathrm{d}(83)$ & - \\
\hline cis-Aconitate & + & - & $\mathrm{d}(20)$ & $\mathrm{d}(80)$ & - & - & + \\
\hline 5-Keto-D-gluconate & - & - & - & d $(20)$ & - & + & + \\
\hline Mannitol & + & + & + & + & + & - & + \\
\hline Lecithin & + & + & + & + & + & - & - \\
\hline ADH Moeller & $\mathrm{d}(15)$ & - & + & - & d (69) & - & - \\
\hline meso-Tartrate & + & $\mathrm{d}(75)$ & - & + & + & + & + \\
\hline
\end{tabular}

the type species of the genus, are phylogenetically distantly related to the novel genus Dickeya.

\section{Taxonomic conclusions}

Based on the above-mentioned phylogenetic analyses, which show that eight 16S rRNA gene sequences of the $E$. chrysanthemi complex form a clade distinct from the genera Pectobacterium and Brenneria, we propose that P. chrysanthemi be reclassified as the first species of a novel genus, Dickeya, as Dickeya chrysanthemi. Six DNA-DNA hybridization groups were delineated within the E. chrysanthemi complex corresponding to the six genomic species described herein that we propose to identify as six species. Biochemical characteristics and serological reactions presented above allowed identification of these six species. Therefore, the six genomic species being in accordance with the phylogenetic definition of bacterial species of Wayne et al. (1987), we propose for them the following names: Dickeya chrysanthemi, Dickeya dadantii, Dickeya dianthicola, Dickeya dieffenbachiae, Dickeya paradisiaca and Dickeya zeae.

Considering the discrepancies observed between four $16 \mathrm{~S}$ rRNA gene sequences of $P$. cypripedii deposited in the databases, the phylogenetic position of this species remains uncertain. The strain giving the nearest sequence (GenBank accession no. Z96094) showed such low DNA relatedness with Dickeya species that it might be supposed not to be related to this genus.

\section{Description of Dickeya gen. nov.}

Dickeya (Dic.ke'ya. N.L. fem. n. Dickeya after the American phytopathologist Robert S. Dickey, for his contribution to research on the Erwinia chrysanthemi complex).
The genus description is based on our data and those of Waldee (1945) and Hauben et al. (1998). Cells are Gramnegative rods, $0 \cdot 5-1 \cdot 0 \times 1 \cdot 0-3 \cdot 0 \mu \mathrm{m}$ with rounded ends. They occur mostly alone or in pairs, but sometimes in chains. Cells are usually motile by means of peritrichous flagella. Facultatively aero-/anaerobic bacteria that catabolize glucose by a fermentative pathway and reduce nitrates to nitrites. Pectinolytic, produce indole and grow at $36^{\circ} \mathrm{C}$. Catabolize $(+)$-L-arabinose, myo-inositol, (+)-D-malate, malonate, D-mannose, mucate, saccharate and mesotartrate, but do not catabolize $(+)$-D-trehalose, methyl $\alpha$-glucoside, $(+)$-D-arabitol or sorbitol. Cause vascular wilts or soft rots on a range of host plants. Members of the genus Dickeya form a clade as determined by $16 \mathrm{~S}$ rRNA gene sequence analyses. $\mathrm{G}+\mathrm{C}$ contents of the genus range from 56.4 to $59.5 \mathrm{~mol} \%$. The type species is Dickeya chrysanthemi (Burkholder et al. 1953) Samson et al.

\section{Description of Dickeya chrysanthemi comb. nov.}

Dickeya chrysanthemi (chrys.an'the.mi. N.L. gen. n. chrysanthemi of the plant genus Chrysanthemum).

Basonym: Pectobacterium chrysanthemi (Burkholder et al. 1953) Brenner et al. 1973 emend. Hauben et al. 1998.

Has the characteristics of the genus. Additional characteristics are listed in Table 3. Strains belong to two biovars: chrysanthemi (from pv. chrysanthemi pathogenic to Chrysanthemum morifolium; Burkholder et al., 1953) and parthenii (from pv. parthenii described on gayule, Parthenium argentatum; Campbell, 1947). Isolated from soft rot and wilt of various plants, such as Chrysanthemum spp., Cynara scolymus, Cichorium intybus, Helianthus annuus, 
Table 4. Differential phenotypic patterns of strains belonging to phenon 1

\begin{tabular}{|c|c|c|c|c|c|c|c|}
\hline Strain (CFBP no.) & $\alpha$-Lactose & $\begin{array}{c}\text { 1-o-Methyl } \\
\beta \text {-galactopyranoside }\end{array}$ & $\beta$-Gentiobiose & $(+)$-L-Tartrate & L-Alanine & Cellobiose & O-serogroup \\
\hline \multicolumn{8}{|l|}{ Dickeya dadantii } \\
\hline 4151 & - & - & + & - & - & - & 6 \\
\hline 4152 & - & - & + & - & - & - & 6 \\
\hline 4153 & - & - & + & - & - & + & 1 \\
\hline 2018 & - & - & - & - & - & - & 1 \\
\hline 3697 & + & - & - & - & - & - & 1 \\
\hline 1613 & - & + & - & - & - & + & 1 \\
\hline 3780 & + & + & + & - & - & + & 1 \\
\hline 1528 & + & + & - & + & - & - & 10 \\
\hline 1884 & + & + & - & + & - & - & 11 \\
\hline 3708 & + & + & - & + & - & + & $?$ \\
\hline 4176 & + & + & - & + & - & + & 6 \\
\hline 1871 & + & + & - & + & + & + & $?$ \\
\hline 3707 & + & + & - & + & + & + & 1 \\
\hline 6466 & + & + & - & + & + & + & 10 \\
\hline 1496 & + & + & - & - & - & - & 5 \\
\hline 4149 & + & + & - & - & - & + & $?$ \\
\hline 4148 & + & + & - & - & + & + & $?$ \\
\hline 1533 & + & - & + & - & - & + & $?$ \\
\hline \multicolumn{8}{|l|}{ Dickeya sp. } \\
\hline 1278 & - & + & - & + & + & + & 7 \\
\hline 1537 & + & + & + & - & - & - & 7 \\
\hline
\end{tabular}

Lycopersicon esculentum, Parthenium argentatum and Philodendron spp. Serogroups O: 1 and $\mathrm{O}: 2$.

The type strain is CFBP $2048^{\mathrm{T}}\left(=\mathrm{NCPPB} 402^{\mathrm{T}}=\mathrm{ICMP}\right.$ $5703^{\mathrm{T}}=\mathrm{LMG} 2804^{\mathrm{T}}$ ); its $\mathrm{G}+\mathrm{C}$ content is $58 \cdot 8 \mathrm{~mol} \%$.

\section{Description of Dickeya dadantii sp. nov.}

Dickeya dadantii (da.dan.ti'i. N.L. gen. masc. n. dadantii of Dadant, in honour of the phytopathologist R. Dadant, for his description of the bacterium isolated from diseased Pelargonium capitatum).

Has the characteristics of the genus. Additional characteristics are listed in Table 3. Part of ex Pectobacterium chrysanthemi biovar 3 . Isolated from soft rot and wilt of a range of plants, such as Pelargonium capitatum, Ananas comosus, Dianthus spp., Euphorbia pulcherrima, Ipomoea batatas, Musa spp., Philodendron spp., Saintpaulia ionantha and Zea mays. Serogroups O: 1 and O:6.

The type strain is CFBP $1269^{\mathrm{T}}\left(=\mathrm{NCPPB} 898^{\mathrm{T}}=\mathrm{ICMP}\right.$ $1544^{\mathrm{T}}=$ Hayward $\mathrm{B} 374^{\mathrm{T}}$ ); its $\mathrm{G}+\mathrm{C}$ content is $59 \cdot 5 \mathrm{~mol} \%$.

\section{Description of Dickeya dianthicola sp. nov.}

Dickeya dianthicola (di.an.thi.co'la. N.L. n. dianthicola the dweller of Dianthus sp.).

The description of the species is after 'Pectobacterium parthenii-dianthicola' described on Dianthus sp. (Hellmers, 1955). Has the characteristics of the genus. Additional 


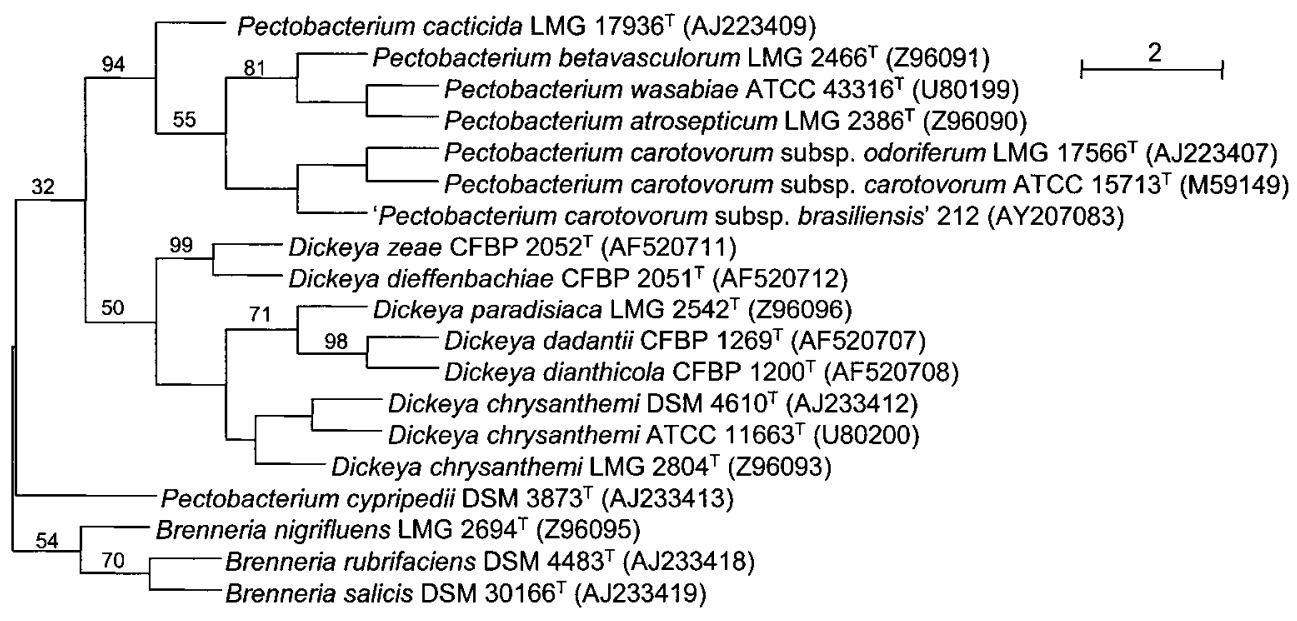

Fig. 2. Unrooted tree, the result of a phylogenetic analysis (parsimony shown) of $16 \mathrm{~S}$ rRNA gene sequences of type strains of Dickeya, Pectobacterium and Brenneria species. Bootstrap values (expressed as percentages of 1000 replications, $\mathrm{BIONJ}+$ Kimura two-parameter) are indicated only for branches also retrieved by BIONJ and maximum-likelihood analyses $(P<0.01)$.

characteristics are listed in Table 3. Strains belong to ex Pectobacterium chrysanthemi biovars 1, 7 and 9. Isolated from soft rot and wilt of various plants, such as Dianthus spp., Cichorium intybus, Cynara scolymus, Dahlia variabilis, Kalanchoe blossfeldiana, Lycopersicon esculentum and Solanum tuberosum. Serogroup O 1 .

The type strain is CFBP $1200^{\mathrm{T}}\left(=\mathrm{NCPPB} 453^{\mathrm{T}}=\mathrm{ICMP}\right.$ $6427^{\mathrm{T}}=$ LMG $\left.2485^{\mathrm{T}}\right)$; its $\mathrm{G}+\mathrm{C}$ content is $59 \cdot 5 \mathrm{~mol} \%$.

\section{Description of Dickeya dieffenbachiae sp. nov.}

Dickeya dieffenbachiae (dief.fen.ba'chi.ae. N.L. gen. n. dieffenbachiae of the plant genus Dieffenbachia).

The description (after 'Erwinia dieffenbachiae' described on Dieffenbachia sp.; McFadden, 1961) is the same as for the genus. Additional characteristics are listed in Table 3. Strains belong to ex Pectobacterium chrysanthemi biovar 2. Isolated from soft rot and wilt of Dieffenbachia spp., Lycopersicon esculentum and Musa spp. Serogroup O: 1 .

The type strain is CFBP $2051^{\mathrm{T}}\left(=\mathrm{NCPPB} 2976^{\mathrm{T}}=\mathrm{ICMP}\right.$ $\left.1568^{\mathrm{T}}\right)$; its $\mathrm{G}+\mathrm{C}$ content is $57 \cdot 9 \mathrm{~mol} \%$.

\section{Description of Dickeya paradisiaca comb. nov.}

Dickeya paradisiaca (pa.ra.di.si.a'ca. L. fem. adj. paradisiaca of or belonging to paradise, referring to the isolation of the organism from Musa paradisiaca).

Basonym: Erwinia paradisiaca Fernandez-Borrero and Lopez-Duque 1970.

Other synonyms: Pectobacterium chrysanthemi biovar 4; Brenneria paradisiaca.

The description (after Erwinia paradisiaca described on
Musa paradisiaca; Fernandez-Borrero \& Lopez-Duque, $1970)$ is the same as for the genus. Additional characteristics are listed in Table 3. Strains have been isolated from soft rot and wilt of Musa spp. and Zea mays. Serogroup O:3.

The type strain is CFBP $4178^{\mathrm{T}}\left(=\mathrm{NCPPB} 2511^{\mathrm{T}}=\mathrm{LMG}\right.$ $\left.2542^{\mathrm{T}}\right)$; its $\mathrm{G}+\mathrm{C}$ content is $58 \cdot 0 \mathrm{~mol} \%$.

\section{Description of Dickeya zeae sp. nov.}

Dickeya zeae (ze'ae. N.L. gen. n. zeae of the plant genus Zea).

The description (after Erwinia carotovora f. sp. zeae described on maize; Sabet, 1954) is the same as for the genus. Additional characteristics are listed in Table 3. Strains are part of ex Pectobacterium chrysanthemi biovars 3 and 8. Isolated from soft rot and wilt of a various range of plants, such as Zea mays, Ananas comosus, Brachiaria ruziziensis, Chrysanthemum morifolium, Musa spp., Nicotiana tabacum, Oryza sativa and Solanum tuberosum, and from water. More than nine $\mathrm{O}$-serogroups $(\mathrm{O}: 1, \mathrm{O}: 4, \mathrm{O}: 5, \mathrm{O}: 6, \mathrm{O}: 8, \mathrm{O}: 9$, $\mathrm{O}: 10, \mathrm{O}: 11, \mathrm{O}: 12$, and untyped strains).

The type strain is CFBP $2052^{\mathrm{T}}\left(=\mathrm{NCPPB} 2538^{\mathrm{T}}=\mathrm{ICMP}\right.$ $5704^{\mathrm{T}}=\mathrm{LMG} 2505^{\mathrm{T}}$ ); its $\mathrm{G}+\mathrm{C}$ content is $56 \cdot 4 \mathrm{~mol} \%$.

\section{ACKNOWLEDGEMENTS}

We thank Sophie Bonneau and Solange Belouin for their helpful assistance.

\section{REFERENCES}

Avrova, A. O., Hyman, L. H., Toth, R. L. \& Toth, I. K. (2002). Application of amplified fragment length polymorphism fingerprinting for taxonomy and identification of the soft rot bacteria Erwinia 
carotovora and Erwinia chrysanthemi. Appl Environ Microbiol 68, 1499-1508.

Boccara, M., Vedel, R., Lalo, D., Lebrun, M. H. \& Lafay, J. F. (1991). Genetic diversity and host range in strains of Erwinia chrysanthemi. Mol Plant Microb Interact 4, 293-299.

Brenner, D. J., Steigerwalt, A. G., Miklos, G. V. \& Fanning, G. R. (1973). Deoxyribonucleic acid relatedness among erwiniae and other Enterobacteriaceae: the soft-rot organisms (genus Pectobacterium Waldee). Int J Syst Bacteriol 23, 205-216.

Brenner, D. J., Fanning, G. R. \& Steigerwalt, A. G. (1977). Deoxyribonucleic acid relatedness among erwiniae and other enterobacteria. II. Corn stalk rot bacterium and Pectobacterium chrysanthemi. Int J Syst Bacteriol 27, 211-221.

Brenner, D. J., McWhorter, A. C., Knutson, J. K. \& Steigerwalt, A. G. (1982). Escherichia vulneris: a new species of Enterobacteriacae associated with human wounds. J Clin Microbiol 15, 1133-1140.

Burkholder, W. H. (1957). Genus VI. Erwinia Winslow et al. 1917. In Bergey's Manual of Determinative Bacteriology, 7th edn, pp. 349-359. Edited by R. S. Breed, E. G. D. Murray \& N. R. Smith. Baltimore: Williams \& Wilkins.

Burkholder, W. H., MacFadden, L. H. \& Dimock, A. H. (1953). A bacterial blight of chrysanthemums. Phytopathology 43, 522-525.

CABI (2001). Crop Protection Compendium. Wallingford, UK: CAB International. CD-ROM; http://www.cabicompendium.org/cpc

Campbell, W. A. (1947). A bacterial root and stem disease of gayule. Phytopathology 37, 271-277.

Crosa, J. H., Brenner, D. J. \& Falkow, S. (1973). Use of a singlestrand specific nuclease for analysis of bacterial and plasmid deoxyribonucleic acid homo- and heteroduplexes. J Bacteriol 115, 904-911.

Descamp, P. \& Véron, M. (1981). Une méthode de choix des caractères d'identification basée sur le théorème de Bayes et la mesure de l'information. Ann Microbiol 132B, 157-170 (in French).

Dickey, R. S. (1979). Erwinia chrysanthemi: a comparative study of phenotypic properties of strains from several hosts and other Erwinia species. Phytopathology 69, 324-329.

Dickey, R. S. (1981). Erwinia chrysanthemi: reaction of eight plants to strains from several hosts and to strains of other Erwinia species. Phytopathology 71, 23-29.

Dickey, R. S. \& Victoria, J. I. (1980). Taxonomy and emended description of strains of Erwinia isolated from Musa paradisiaca Linnaeus. Int J Syst Bacteriol 30, 129-134

Dickey, R. S., Zumoff, C. H. \& Uyemoto, J. K. (1984). Erwinia chrysanthemi: serological relationships among strains from several hosts. Phytopathology 74, 1388-1434.

Dickey, R. S., Claflin, L. E. \& Zumoff, C. H. (1987). Erwinia chrysanthemi: serological comparisons of strains from Zea mays and other hosts. Phytopathology 77, 426-430.

Dye, D. W. (1969). A taxonomic study of the genus Erwinia. II. The 'carotovora' group. $N Z$ J Sci 12, 81-97.

Fernandez-Borrero, O. \& Lopez-Duque, S. (1970). Pudricion acuosa des seudo tallo del plátano (Musa paradisiaca) causada por Erwinia paradisiaca, n. sp. CENICAFE 21, 3-44 (in Spanish)

Felsenstein, J. (1995). PHYLIP (phylogeny inference package), version 3.57c. Distributed by the author. Department of Genome Sciences, University of Washington, Seattle, USA.

Gardan, L., Gouy, C., Christen, R. \& Samson, R. (2003). Elevation of three subspecies of Pectobacterium carotovorum to species level: Pectobacterium atrosepticum sp. nov., Pectobacterium betavasculorum sp. nov. and Pectobacterium wasabiae sp. nov. Int J Syst Evol Microbiol 53, 381-391.
Gascuel, O. (1997). BIONJ: an improved version of the NJ algorithm based on a simple model of sequence data. Mol Biol Evol 14, 685-695.

Graham, D. C. (1964). Taxonomy of the soft rot coliform bacteria. Annu Rev Phytopathol 2, 13-42.

Graham, D. C. (1972). Identification of soft rot coliform bacteria. In Proceedings of the 3rd International Conference on Plant-Pathogenic Bacteria, pp. 273-279. Edited by H. P. Maas-Geesteranus. Wageningen: Pudoc.

Grimont, P. A. D., Popoff, M. Y., Grimont, F., Coynault, C. \& Lemelin, M. (1980). Reproducibility and correlation study of three deoxynucleic acid hybridization procedures. Curr Microbiol 4, 325-330.

Guillorit-Rondeau, C., Malandrin, L. \& Samson, R. (1996). Identification of two serological flagellar types (H1 and $\mathrm{H} 2)$ in Pseudomonas syringae pathovars. Eur J Plant Pathol 102, 99-104.

Hauben, L., Moore, E. R. B., Vauterin, L., Steenackers, M., Mergaert, J., Verdonck, L. \& Swings, J. (1998). Phylogenetic position of phytopathogens within the Enterobacteriaceae. Syst Appl Microbiol 21, 384-397.

Hellmers, E. (1955). Bacterial wilt of carnations. Gard Chron 137, 194.

Hildebrand, D. C., Schroth, M. N. \& Thomson, S. (1978). Nutritional properties useful for identification of soft-rotting Erwinia species. In Proceedings of the 4th International Conference on Plant-Pathogenic Bacteria, pp. 561-562. Edited by M. Ridé. Angers: INRA.

Janse, J. D. \& Ruissen, M. A. (1988). Characterization and classification of Erwinia chrysanthemi strains from several hosts in The Netherlands. Phytopathology 78, 800-808.

Lelliott, R. A. \& Dickey, R. S. (1984). Genus VII. Erwinia Winslow, Broadhurst, Buchanan, Krumwiede, Rogers and Smith 1920, 209 ${ }^{\mathrm{AL}}$. In Bergey's Manual of Systematic Bacteriology, vol. 1, pp. 469-476. Edited by N. R. Krieg \& J. G. Holt. Baltimore: Williams \& Wilkins.

Martinec, T. \& Kocur, M. (1963). Taxonomicka studie rodu Erwinia. Fol Biol 2, 1-163 (in Czech).

McFadden, L. A. (1961). Bacterial stem and leaf rot of Dieffenbachia in Florida. Phytopathology 51, 663-668.

Nassar, A., Bertheau, Y., Dervin, C., Narcy, J. P. \& Lemattre, M. (1994). Ribotyping of Erwinia chrysanthemi strains in relation to their pathogenic and geographic distribution. Appl Environ Microbiol 60, 3781-3789.

Nassar, A., Darrasse, A., Lemattre, M., Kotoujansky, A., Dervin, C. Vedel, R. \& Bertheau, Y. (1996). Characterization of Erwinia chrysanthemi by pectinolytic isozyme polymorphism and restriction fragment length polymorphism analysis of PCR-amplified fragments of pel genes. Appl Environ Microbiol 62, 2228-2235.

Ngwira, N. \& Samson, R. (1990). Erwinia chrysanthemi: description of two new biovars (bv 8 and bv 9) isolated from kalanchoe and maize host plants. Agronomie 10, 341-345.

Perrière, G. \& Gouy, M. (1996). WWW-query: an on-line retrieval system for biological sequence banks. Biochimie 78, 364-369.

Rasolofo, R. \& Dadant, R. (1962). Dépérissement du géranium rosat Pelargonium capitatum aux Comores. Agron Trop 12, 1084-1088 (in French).

Sabet, K. A. (1954). A new bacterial disease of maize in Egypt. Emp J Exp Agric 22, 65-67.

Samson, R. (1973). Les erwinias pectinolytiques. II - Recherches sur les antigènes somatiques d'Erwinia carotovora var. chrysanthemi (Burkholder) Dye. Ann Phytopathol 5, 377-388 (in French).

Samson, R. \& Nassan-Agha, N. (1978). Biovars and serovars among strains of Erwinia chrysanthemi. In Proceedings of the 4th 
International Conference on Plant-Pathogenic Bacteria, pp. 547-553. Edited by M. Ridé. Angers: INRA.

Samson, R., Poutier, F., Sailly, M. \& Jouan, B. (1987). Caractérisation des Erwinia chrysanthemi isolées de Solanum tuberosum et d'autres plantes-hôtes selon les biovars et sérogroupes. Bull OEPP 17, 11-16 (in French).

Samson, R., Ngwira, N. \& Rivera, N. (1990). Biochemical and serological diversity of Erwinia chrysanthemi. In Plant-Pathogenic Bacteria, Proceedings of the 7th International Conference on PlantPathogenic Bacteria, pp. 895-900. Edited by Z. Klement. Budapest: Akademia Kiado.

Skerman, V. B. D., McGowan, V. \& Sneath, P. H. A. (1980). Approved lists of bacterial names. Int $J$ Syst Bacteriol 30, 225-420.

Sneath, P. H. A. \& Sokal, R. R. (1973). Numerical Taxonomy: the Principles of Numerical Classification. San Francisco: W. H. Freeman.

Sutra, L., Christen, R., Bollet, C., Simoneau, P. \& Gardan, L. (2001). Samsonia erythrinae gen. nov., sp. nov., isolated from bark necrotic lesions of Erythrina sp., and discrimination of plant-pathogenic
Enterobacteriaceae by phenotypic features. Int J Syst Evol Microbiol 51, 1291-1304.

Thomson, S. V., Hildebrand, D. C. \& Schroth, M. N. (1981). Identification and nutritional differentiation of the Erwinia sugar beet pathogen from members of Erwinia carotovora and Erwinia chrysanthemi. Phytopathology 71, 1037-1042.

Verdonck, L., Mergaert, J., Rijckaert, C., Swings, J., Kersters, K. \& De Ley, J. (1987). Genus Erwinia: numerical analysis of phenotypic features. Int J Syst Bacteriol 37, 4-18.

Waldee, E. L. (1945). Comparative studies of some peritrichous phytopathogenic bacteria. Iowa State J Sci 19, 435-484.

Wayne, L. G., Brenner, D. J., Colwell, R. R. \& 9 other authors (1987). International Committee on Systematic Bacteriology. Report of the ad hoc committee on reconciliation of approaches to bacterial systematics. Int J Syst Bacteriol 37, 463-464.

Yakrus, M. \& Schaad, N. W. (1979). Serological relationships among strains of Erwinia chrysanthemi. Phytopathology 69, 517-522.

Young, J. M., Dye, D. W., Bradbury, J. F., Panagopoulos, C. G. \& Robbs, C. F. (1978). A proposed nomenclature and classification for plant-pathogenic bacteria. N Z J Agric Res 21, 153-177. 